\title{
REGIONAL DEVELOPMENT AND CLIMATE CHANGE ADAPTATION: A STUDY OF THE ROLE OF LEGITIMACY
}

\author{
Erik Thorstensen, Ellen-Marie Forsberg, Anders Underthun ${ }^{1}$, \\ Pavel Danihelka, Jakub Reháček ${ }^{2}$
}

\footnotetext{
${ }^{1}$ Erik Thorstensen [corresponding author], MA, Ellen-Marie Forsberg, PhD., Anders Underthun, PhD, Work Research Institute, Centre for Welfare and Labour Research, Oslo and Akershus University College of Applied Sciences, PO box 4, St. Olavs plass, 0130 Oslo, erik.thorstensen@afi.hioa.no, ellenmarie.forsberg@afi.hioa.no, anders.underthun@afi.hioa.no

2 Prof. RNDr. Pavel Danihelka CSc, Ing. Jakub Řeháček., Laboratory for Risk Research \& Management, FBI - Faculty of Safety Engineering, VŠB - Technical University of Ostrava, Lumírova 13, Ostrava, pavel.danihelka@vsb.cz; jakub.rehacek@gmail.com
} 


\begin{abstract}
This paper presents results from a study of Czech Local Action Groups (LAGs), focusing on gaining knowledge about their internally perceived legitimacy and their potential role in local adaptation to climate change. Former studies on the role of governance networks in climate change adaptation have suggested that these networks' legitimacy are crucial for their success. In this article we provide an analytical framework that can be used to address different aspects of local governance networks which are important for their legitimacy and the way they are apt as instruments for climate change adaptation actions. We also present a survey among LAG members that provide empirical data that we discuss in the article. The framework and the data are discussed with reference to existing contributions in the intersection of legitimacy, governance networks and climate change adaptation. A specific aim is to provide research based recommendations for further improving LAGs as an adaptation instrument. In addition, knowledge is generated that will be interesting for further studies of similar local governance initiatives in the climate change adaptation context.
\end{abstract}

Keywords: Local Action Groups; The Czech Republic; Legitimacy; Adaptation to climate change

Abstrakt: Tento článek prezentuje výsledky výzkumu zaměřeného na české místní akční skupiny (MAS). Výzkum byl zaměřen na získání povědomí o jejich interně vnímané legitimitě a možné roli MAS v rámci lokální adaptace na klimatickou změnu v ČR. Předchozí studie zaměřené na roli organizací podporujících dobré vládnutí v oblasti adaptace na klimatickou změnu ukazují, že legitimita těchto organizací je pro jejich úspěch naprosto klíčová. Tento článek poskytuje také vhled do analytického rámce použitelného jak pro budování legitimity, tak dalších aspektů, které mohou být vhodné pro podporu dobrého vládnutí MAS a jim podobných struktur $v$ rámci adaptace na klimatickou změnu. Součástí článku je rozbor empirických dat $z$ dotazníkového šetření získaných metodou survey mezi členy MAS. Analytický rámec a získaná data jsou diskutována s ohledem na již existující odborné příspěvky zaměřené na legitimitu, organizace podporující dobré vládnutí a na adaptaci na klimatickou změnu. Specifickým cílem tohoto příspěvku je poskytnout doporučení založená na vědeckém výzkumu pro zlepšování Místních akčních skupin jako nástroje pro adaptaci na klimatickou změnu. Navíc mohou být výsledky zajímavé pro další rozvoj organizací zaměřených na dobré vládnutí v oblasti adaptace na klimatickou změnu na území ČR.

Klíčová slova: Místní akční skupina; Česká Republika; Legitimita; Adaptace na klimatickou změnu

\title{
1. Introduction
}

This article presents and discusses how a selection of members of Local Action Groups (LAGs) in the Czech Republic perceive the legitimacy of LAGs within the context of adaptation to climate change. Local Action Groups are part of the European Union's rural and local development policy. Their origin is in the European Commission's Community initiative LEADER (Liaisons Entre Actions de Développement de l'Economie Rurale [Links between the rural economy and development actions]) from 1991 (Maurel 2008). LEADER is currently organized under the European Commission's European Network for Rural Development. ${ }^{3}$ The European Commission's philosophy behind the LEADER programme is that local development strategies should be "decided and implemented at local level by local actors" $(2006,8)$. For the period

\footnotetext{
${ }^{3}$ http://enrd.ec.europa.eu/en
} 
2014 - 2020, the National Network of Local Action Groups in the Czech Republic (2011) estimate that an average LAG will have 4 million Euro per year to support local initiatives.

To date, research on the Czech LAGs has focused on how LAG members perceive the LAGs and their roles. This article presents results from the project "Resilience and adaptation to climate change in regional strategies" where a key rationale has been to develop understanding of advantages, potentials and challenges of building resilience to climate change within Czech LAGs. Through the work in this project we show that a focus on legitimacy provides a novel perspective on this governance structure, which allows us to pinpoint dimensions that have a crucial role in building effective institutions that can handle complex issues such as adaptation to and mitigation of climate change.

The data for the article consist of responses to a survey distributed at the start of a series of regional workshops on adaptation and resilience to climate change in ten different locations in each of the ten Czech regions in the spring and early summer of 2015.

Our approach in the study follows Forsberg's (2012a) perspective on networked development through the lens of institutional legitimacy, and studies the LAG members' perception of the legitimacy dimensions of their organisation in the context of adaptation and resilience to climate change. The current paper then responds to calls for empirical studies on institutional legitimacy expressed by a range of authors (Kumar \& Das 2007; Low \& Johnston 2010; Persson et al. 2012), and we also argue that our study respond to neo-endogenous thinking in terms of bridging questions of legitimacy at the local level to the issue of finding global solutions to climate change (Ray 1999; Ward et al. 2005; Scott 2013).

Legitimate structures and working methods (and the study of such) are important because LAGs have a broader impact on societal change, positive or negative. Indeed, Maurel states that the current governance of Czech LAGs may even "have the effect of hampering the learning of civic involvement at a local level" $(2008,64)$. Knowledge is thus needed and this article is a contribution to this.

The paper sets out to present the issue of legitimacy from an organisational institutionalist perspective, with a particular focus on the perceptions of the organisation's members (Suchman 1995; Kumar \& Das 2007). Here, the object of study is not the formal political legitimacy of an institution as studied in the political sciences, but rather the support various features of an institution or organization has amongst its members. The first section of the paper thus introduces an institutionalist understanding of legitimacy, followed by a section on adaptation strategies and legitimacy. Subsequently, we present current research on LAGs in the Czech Republic and elsewhere, with an emphasis on issues relevant to a discussion and analysis of legitimacy. We then present the methods used in the collection and analysis of data before presenting the data in different forms and according to identified background parameters. We proceed to a discussion of the findings related to earlier literature and other variables in the survey and in the final and concluding section we discuss the implications of our findings. We believe that our findings are not only interesting because they generate research based recommendations for further improving LAGs an adaptation instrument. They also generate knowledge that will be valuable for further studies of similar local governance initiatives in the climate change adaptation context.

\section{Perspectives on institutional legitimacy}

Following Mark Suchman's (1995) understanding of legitimacy, we will study the LAGs as institutions based on a notion of internal or interpartner legitimacy (Kumar \& Das 2007). Suchman's general definition understands legitimacy as "a generalized perception or assumption that the actions of an entity are desirable, proper, or appropriate within some socially constructed system of norms, values, beliefs, and definitions" (Suchman 1995, 574). In a later article Deephouse and Suchman write: "The consequences of legitimacy have also received considerable attention ... [I]nstitutionalists have argued that legitimacy enhances organizational survival. Supportive evidence abounds" $(2008,58)$. Suchman's account is sociological in that it 
views legitimacy as a socially constructed and relational entity within an institution as well as between an institution and its environment.

Studies of social legitimacy of and in organizations often cite Max Weber's (1947) work as a crucial starting point. Weber's studies of different types of authority as sources for social action was later taken up by Talcott Parsons (1960) - and from him the concepts of legitimacy found their way into organizational studies. This field studies how organizations enjoy different types and degrees of support in and for different subject areas. Some organizations are supported because they are perceived to be rationally effective while others provide for the sustenance and creation of socially valued goods (Deephouse \& Suchman 2008).

The pragmatic legitimacy of an institution depends on the "self-interested calculations of an organization's most immediate audiences" (Suchman 1995, 578). Suchman writes that pragmatic legitimacy should primarily be understood as a type of exchange legitimacy, addressing the question of the value of the organisation to its constituents.

Moral legitimacy is created from evaluators' beliefs that the activities perceived to be produced by the organization are the right things to do. The higher the fit between a person's value system and the organization, the higher the moral legitimacy of that organization will be. ${ }^{4}$

Finally, cognitive legitimacy refers to a situation where constituents understand the organization's rational and working methods, even to the extent where is becomes a self-evident part of society.

Suchman is here focusing on external legitimacy, i.e. how the broader societal environment perceives an institution or organization. Persson et al. (2011) study internal or interpartner legitimacy. Interpartner legitimacy refers to "the acceptance of an organization by its internal constituencies" (Persson et al. 2011, 1024). Kumar and Das translate Suchman's taxonomy for external legitimacy into notions of internal legitimacy. Here, interpartner pragmatic legitimacy refers to a situation where "alliance members see their involvement and contribution as furthering their own interests and the interests of the (larger) alliance" (Kumar \& Das 2007, 1434). Moral interpartner legitimacy means that "member firms form judgments about whether the specific alliance is the right thing to do" (Kumar \& Das 2007, 1434). Cognitive legitimacy is achieved when the members see their participation as natural and necessary within their larger strategic context (Kumar \& Das 2007).

The research focus in this paper will be the perception of LAGs by their members. A similar study of legitimacy of LAGs in Denmark, Finland and Sweden was conducted by Thuesen (2010). According to Thuesen there are three different levels, approaches and theories that can be applied to the study of LAGs.

We have followed Thuesen (2011) in studying input and output legitimacy of Czech LAGs at a local level through questionnaires. This means that we study the LAGs as procedural entities; that is, how they are composed and how they work in order to achieve outcomes (Forsberg 2012 b). In addition to Thuesen's perspective, we add the throughput-dimension of legitimacy.

Input legitimacy is related to who participates in an institution, such as a regional development network. Output legitimacy refers to what Suchman (1995), Kumar and Das (2007) have called pragmatic legitimacy, namely the production of value for the constituents. Throughput legitimacy refers to the legitimacy of the design of the decision or development process; to a procedural notion of fairness or acceptability, which then corresponds to an aspect of Kumar and Das' notion of moral interpartner legitimacy (Dingwerth 2007). To sum up, where Suchman (1995) and Kumar and Das (2007) study how institutions are perceived as entities through the notions of moral, pragmatic and cognitive legitimacy, in this study we follow Forsberg (2012a; 2012b) focus on studying how their working processes are perceived.

\footnotetext{
${ }^{4}$ Forsberg (2012a) argues that this dimension instead should be called 'normative legitimacy' because Suchman does not refer to commonly held ethical principles, but rather to any particular value system an individual or a group may embrace.
} 


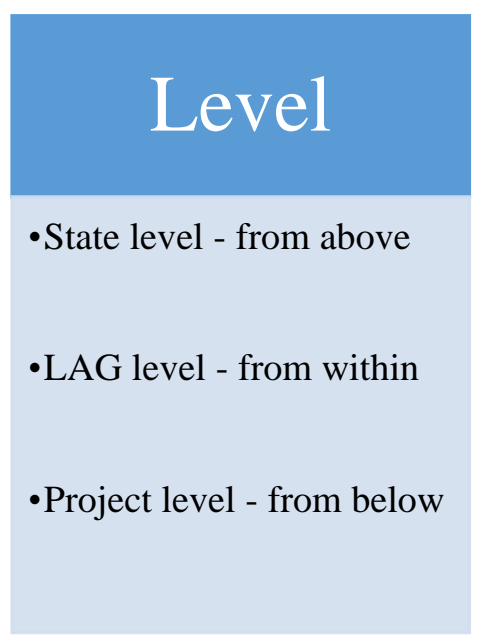

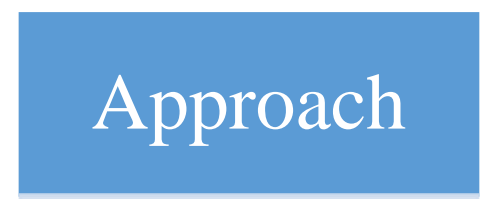

-Democracy and governance

- Organisational processes

-Projects and results

\section{Theories}

-Democracy,

selfgovernance and

metagovernance

-Management and

strategy, collaborative

advantages

- Catalytic impacts, soft and hard indicators, transformative potentials

Fig 1. Possible approaches to a study of LEADER LAGs (Thuesen 2010, 16).

In the context of mitigation and the Clean Development Mechanism (CDM) under the Kyoto Protocol, Lederer (2011) addresses the connections between input, throughput and output legitimacy. He concludes that there is no necessary relationship between these three forms of legitimacy and that the ties between them is rather - in a sociological sense - an empirical rather than a theoretical question. However, he acknowledges that it is reasonable to hold that "the solution to a problem would not be perceived as legitimate if the process of getting there did not take into account the interests of its stakeholders in some form or another and vice versa" (Lederer 2011, 1901). Consequently, in the empirical material for this paper, one should expect a correlation between the throughput and the output dimensions of legitimacy.

\section{Adaptation to Climate Change and Legitimacy}

Currently, the state of knowledge on costs and benefits of adaptation to climate change varies greatly between sectors (ECONADAPT 2015). It is hard to imagine that any single decision-maker in the public or in the private sector could have the full overview of possible impacts from climate change (OECD 2015). From the beginning of the 1990s, governments have therefore sought to engage the public in issues related to climate change. This engagement has had two types of rationale: Sometimes the public has been engaged in order to educate them about the causes and effects of climate change, and in other instances governments have sought the advice of how public knowledge can improve policy developments (Bulkeley \& Newell 2010). Since the beginning of the 2000s, the issue of public-private partnership has become a central approach to adaptation to climate change world-wide (Bäckstrand 2008), and these are currently promoted as one of the suggested financial arrangements to climate change adaptation (OECD 2015). The 2014 IPCC report on adaptation states: "Climate adaptation is context dependent and it is uniquely linked to location, making it predominantly a local government and community level of action" $(2014,875)$. They key element in these plans is the application of local knowledge in order to strengthen community level adaptation. The rationale is that the local population might be aware of other types of vulnerability or know about different forms of impacts that can affect areas (Wynne 1996; Majule et al. 2013).

Local governments, on their side, depend on effective forms of decision-making as well as knowledge about the risk of unforeseen events and their potential consequences - events that might also be brought about by their own decisions (Urwin \& Jordan 2008; IPCC 2014). Lack of local cooperation might lead to overreliance on technological fixes (Glaas et al. 2010). The EU 2013 Adaptation Strategy lists work with stakeholders as the primary tool in order to "bridge the knowledge gap" (European Commission 2013) and Ensor and Berger (2009) conclude that resilient strategies must be developed in a participatory way. Community-based adaptation will be sensitive cultural values since it takes local knowledge as a point of departure. The use of local and indigenous knowledge is further supported by the Sendai Framework for Disaster Risk Reduction, (Weichselgartner \& Pigeon 2015). 
Winsvold et al. (2009) see governance networks as a way of avoiding failures in adaptation efforts due to insufficiencies in hierarchical and market based approaches. They argue that governance networks might increase participation, but decrease the procedural dimension of democracy as equal access and transparency. In their study of barriers to successful adaptation, Moser \& Ekstrom (2010) see lack of legitimacy as a potential barrier in several phases of adaptation implementation. These new forms of governance networks pose challenges to the classic mode of thinking in liberal democracy since they present an alternative mode of governing where the "people" is no longer pre-given as it is in most accounts of liberal democracy. Further, in governance networks, the decision-makers are not linked to the people through a notion of "representation", and in governance networks there is no longer a firm demarcation between the political system and the rest of society (Sørensen 2002).

These studies show that network based strategies to climate change adaptation and resilience are required, but that their perceived legitimacy will be important for their success. The questions for us are whether the LAGs can play a successful role in climate change adaptation. We will therefore now review some of the assessments and discussions that have been ongoing regarding the LEADER programme and LAGs. This will allow us to form hypotheses on different legitimacy dimensions and contextualise our findings.

\section{Earlier findings that can be related to legitimacy}

A central feature of the LEADER programme is to develop social capital and facilitate crosssectorial learning in rural areas (European Commission 2006; Dwyer \& Findeis 2008). Research on Hungarian LAGs document a capacity for starting projects aimed at discoveries through the examinations of local aspects, and thereby "turning barriers into potentials" (Varga 2009, 98). In a Danish context, Thuessen and Nielsen find that the participants value the LAGs as "empowering self-governing networks" $(2014,320)$, but they link this directly to the high levels of trust in Danish society. The trust in Czech local and regional governments is similarly quite high (European Commission 2010; OECD 2014). This suggests a role for the LAGs in regional adaptation.

Thuesen (2010) observes that what "the European Commission does not mention is that the establishment of LAGs often implies that decision-making authority is handed over to bodies living their own life next to the traditional system of representative democracy" $(2010,11)$. Thuesen describes how the LEADER approach creates a new form of political structure in communities with a formalized political system based on municipalities, counties, regions etc. This means that the LEADER initiative and the LAGs constitute a move away from sectorial development policies towards an endogenous - or stakeholder-based - approach, a development in line with the expansion of "bottom-up approaches" in the 1990s (Ray 2000).

An analysis of the endogenous model in light of the theory of legitimacy presented above would suggest for the input dimension that development should take place on a regional (or sub-state level) territorial level as opposed to mono-sectorial thinking. As for throughput legitimacy, the endogenous model aims to address the needs and capacities of the local population, and to involve local stakeholders in the development strategy (Ray 2000). In terms of output legitimacy, the endogenous model seeks to keep the benefits from local development in the local community. The overarching aim is to enable and empower the local population to define and drive their own developments rather than depend on EU or national initiatives (Maurel 2008).

Ray (1999) sees the emergence of neo-endogenous development within the theoretical framework of reflexive modernization. Here, the EU's LEADER programme is an exogenous factor that acts "as a catalyst to crystallise various local and extra-local interests to manifest in a particular territorial development initiative" (Ray 1999, 260). The local development initiatives create a moral and institutional ideal of and through local identity. Ulrich Beck suggests that in reflexive modernity, "efficacy and legitimacy have become functions of cooperation" (Beck 2006, 54). A neo-endogenous approach to rural development holds that the view of local areas as fully autochthonous entities does not reflect reality, even if it should be an ideal (Ward et al. 2005). The neo-endogenous model of rural development seeks to increase local ties and capacities 
through participation with external agents and forces. The current project, "Resilience and adaptation to climate change in regional strategies", is an initiative based in neo-endogenous thinking in that it is a co-operation between extraneous experts with local stakeholders in order to connect the local capacity building to address the global issue of climate change (Ray 1999; Ward et al. 2005; Scott 2013). The organisation of the LAGs, however, is still based in an endogenous model, with corresponding expectations of input legitimacy at the local level.

In the Czech Republic and in Europe in general, the composition and functioning of LAGs depend on their history (Thuesen 2010; Pechrová \& Boukalová 2015). There are large local and regional differences in their composition and functioning: some overlap different micro-regions, some are a combination of micro-regions while other again are identical to micro-regions. There are LAGs with a clear presence of voluntary sector or business, while there are others that are dominated by public officials and elected mayors. From an outcome point of view, the legitimacy of LAGs would increase if they are perceived to serve to benefit society. Overviews of projects from LAGs show that the large majority of funded projects are submitted by municipalities (Maurel 2008). Even if this dominance by one of the three partners in the LAGs might go against the learning dimension of the LAGs/LEADER programme and thus run counter to the throughput legitimacy of the LAGs, funding of projects that raise the standard of living, supply infrastructure or renovate public areas would contribute to increase the outcome legitimacy of LAGs.

Seen from the perspective of the European Union, the general image is that the LAGs do not fulfill their intended purpose in terms of cross-sectorial co-operation, inclusion of stakeholders, and novel partnerships. The European Court of Auditors (2010) found that LAGs do not contribute much in achieving local strategy objectives; local strategy objectives are not a significant factor in selecting projects for funding and cross-sectorial innovation or interaction is often missing. Moreover, several of the LAG-funded local development projects would have been eligible under other EU funding programmes, and the operational costs for the LAGs are rather high. The Court of Auditors emphasizes that the European Commission and the national authorities share some of the blame in phenomena as backdating grants, lack of transparency, conflicts of interest and lengthy and cumbersome application procedures. According to the European Court of Auditors (2010), the bottom-up approach did not happen in the LAGs. The local authorities ended up deciding and the LAGs gave a majority of the grants to their own member organizations. In sum, the LAGs did not live up to the LEADER philosophy. The European Court of Auditors follows Maurel in her criticism regarding the transparency of the funding and monitoring procedures, as well as signaling dangers for conflicts of interest. The European Court of Auditors even suggested to replace the LAGs with existing structures that better represent the views and interest of local communities (European Union 2012, 9). Even though the LAGs might provide goods to the local communities, they do not provide these goods in a manner that fits with the intention behind establishing them. The European Court of Auditors thus finds that the LAGs are lacking on all dimensions that we can relate to legitimacy.

Lošták \& Hudečková (2010) presents an analysis of newspaper mentions of LAGs and LEADER. Their material shows that there are large differences between the different LAGs in how often they are mentioned, that there is no correlation between the size of the LAG budget and the occurrences in the press, that there is a low degree of transparency of the LAGs' workings in the public space, that the LEADER+ approach enables (some) LAGs to share best practices, and that LAGs might not be efficient in eliminating social exclusion. Lošták and Hudečková's general view of the LAGs' capacity to fulfill LEADER functions and to achieve important social goals is moderately positive.

Miroslav Delin (2012) finds that farmers are adequately represented in LAGs, even if their relative share in representation has decreased in the later years. However, he finds that internally in the LAGs, farmers are underrepresented in leadership positions and he sees this as an indication of internal exclusions of farmers in the LAGs. Delin's findings suggest that the input legitimacy is not very strong.

Pechrová and Boukalová (2015) show a large degree of co-operation and inspiration between the LAGs on administrative, project, and financial issues. This, they argue, is a finding that 
suggest that the LAGs implement the LEADER principles. However, when it comes to cooperation and 'bottom-up' activities with local inhabitants, the differences between the LAGs are great. They argue that there might be a danger that 'LAG experts' have taken over for local involvement. In an interesting twist of words, Pechrová and Boukalová write "Despite that LAGs are often seen as an instrument of subsidies, they should mainly represent the neoendogenous model of the rural development" $(2015,42)$. The authors move here from the perceived form of output legitimacy to insistence upon that LAGs ought to have a form of input legitimacy.

Hudečková and Lošták (2008) find that farmers' needs are listened to, but in a way that diverts funds to investments to machinery and business facilities instead of realizing collective action in communities. They also emphasize the lack of transparency and openness in the LAGs and suggest that the LAGs' strategies do not support "the most typical features for LEADER such as partnership and networks, people and cooperation (social capital), and the background (roots) of strategies in the regional/local identities" (Hudečková \& Lošt'ák $(2008,563)$.

Based on the reviewed literature, we would expect lower scores on input legitimacy and throughput legitimacy, but higher scores on output legitimacy since recurring issues refer to lack of democracy, skewed representation, lacking engagement with the local community and lacking transparency while the funding through the LAGs produce social goods. We will discuss these hypotheses based on results from our survey, but will first present the method in more detail.

\section{Methods}

The three different forms of legitimacy were measured through a questionnaire distributed before the start of a series of ten workshops on resilience and adaptation to climate change. The questionnaire contained questions regarding views on climate change, adaptation and resilience as well as questions on how the LAG members perceive the LAGs as decision-making institutions. The completion of the questionnaire was an integral part of the programme for the workshops. LAG members hosted the workshops while the research project covered the costs of the workshops. The workshop participants volunteered to participate in one-day workshops organised for all the LAGs in their region. Information concerning the workshops was distributed through the NNLAG, the National Network for Local Action Groups.

A project representative ensured that every participant received a questionnaire: When a participant registered, she or he received a questionnaire in paper format to be filled in and returned to a project member before the workshop programme started to minimize possible bias. It took approximately ten to fifteen minutes to complete the questionnaire. After the workshops a project member transferred the inputs from the questionnaires into a spreadsheet and SPSS was used for statistical analysis. 182 persons received the questionnaire while 158 returned it, giving a response rate of $86.8 \%$. Even though the total number of responses is quite low, the response rate is high and the respondents all have central positions in their respective LAGs.

In this article, we only present the results from the parts of the survey related to legitimacy and the LAGs as institutions for climate change adaptation. We studied the three different aspects of legitimation by posing the following questions:

Tab 1. Questions concerning legitimacy from the questionnaire distributed at the workshops.

\begin{tabular}{|l|}
\hline Input legitimacy \\
\hline $\begin{array}{l}\text { To what extent do you consider that you have been able to actually participate in } \\
\text { the decision-making processes in your LAG }\end{array}$ \\
\hline $\begin{array}{l}\text { To what extent do you think your LAG is committed to ensure a wide range of stakeholders } \\
\text { in their decision-making processes }\end{array}$ \\
\hline In your opinion, do the right people participate in your LAG \\
\hline
\end{tabular}




\section{Throughput legitimacy}

To what extent do you consider your LAG decision-making process to provide fair opportunities for all participants to influence the content of your discussions

To what extent do you consider the decisions in your LAG to be based on effective exchange of arguments amongst participants

To what extent have you been able to access and obtain information about the topics for discussion in your LAG

To what extent do you consider your LAG to be accountable to the citizens for their decisions and their performance

\section{Output legitimacy}

To what extent are LAG decisions beneficial for your organization

In addition, questions were included regarded adaption:

Tab 2. Questions concerning adaptation to climate change.

To what extent do you expect the LAG work to result in improved adaptation to climate change locally

In order to adapt to climate change responsibly the following actions are what are primarily needed:

Increased awareness among stakeholders, the public and politicians

More research about climate change and ways how to mitigate it

A stronger moral stance among stakeholders, the public and politicians

Improvement of regulation (laws, decrees, norms)

Integration of already existing research about climate change and ways how to mitigate it

Improved dialogue between stakeholders

Involvement of the public

Economic incentives

The response alternatives to these questions were based on Likert scales, except for the question whether or not the right people participated in the LAGs which was given a yes / no / don't know alternative. Here we have reduced the five point Likert scales (Very high / high / medium / low / very low) in the questionnaire to tripartite (Very high \& high / medium / low \& very low) in order to make the findings more legible.

In this article we do not only present the responses to these questions, but also explore the relations between the different forms of legitimacy. 


\section{Findings}

\section{Input legitimacy}

For the first question "To what extent do you consider that you have been able to actually participate in the decision-making processes in your LAG?" there is some discrepancy. As shown in table 3, a little less than a third deem to have little possibility to participate, while less than one third report to participate to some extent and more than one third to a large extent.

Tab 3. "To what extent do you consider that you have been able to actually participate in the decision-making processes in your LAG?"

\begin{tabular}{|l|c|}
\hline$N=158$ & Percentage \\
\hline No reply & 3.2 \\
\hline Low / very low extent & 29.1 \\
\hline Medium extent & 29.7 \\
\hline High / very high extent & 38.0 \\
\hline
\end{tabular}

The responses to this question seem to be weakly connected to where people live. People living in towns tend to see themselves as participating to a lesser degree than those living in rural areas $(r=-0.252 ; p<0.01)$.

Table 4 shows that those who perceive their participation to be limited also tend to see the inclusion of stakeholders as lacking.

Tab 4. "To what extent do you think your LAG is committed to ensure a wide range of stakeholders in their decisionmaking processes?" divided on those with positive or negative perception on participation.

\begin{tabular}{|l|c|c|c|}
\hline & $\begin{array}{c}\text { Percentage }(\mathrm{N} \\
=158)\end{array}$ & $\begin{array}{c}\text { Percentage (positive) } \\
(\mathrm{N}=58)\end{array}$ & $\begin{array}{c}\text { Percentage (negative) } \\
(\mathrm{N}=44)\end{array}$ \\
\hline No reply & 3.8 & 0 & 11.4 \\
\hline $\begin{array}{l}\text { Low / very low } \\
\text { extent }\end{array}$ & 24.1 & 6.9 & 59.1 \\
\hline Medium extent & 35.4 & 22.4 & 22.7 \\
\hline $\begin{array}{l}\text { High / very high } \\
\text { extent }\end{array}$ & 36.7 & 70.7 & 6.8 \\
\hline
\end{tabular}

Amongst those who perceive their own participation to be limited, 59.1\% also see the LAGs as lacking in including stakeholders. The sum on lacking stakeholder inclusion for those with a positive view on participation is $24.1 \%$. While there are only $6.8 \%$ of those with a negative view on participation who see stakeholder inclusion to be high, the corresponding view amongst those positive to the degree of participation is $70.7 \%$. Unsurprisingly, there is a strong correlation of 0.645 at 0.01 level of significance for these two input legitimacy questions.

When we look at the question about whether or not the right people participate in the LAGs, as shown in table 5, there is no strong correlation between these responses and the remaining questions regarding input legitimacy. Twice as many believe the right people to participate as the contrary. 
Tab 5. "In your opinion, do the right people participate in your LAG?"

\begin{tabular}{|l|c|}
\hline$(\mathrm{N}=158)$ & Percent \\
\hline No reply & 3.2 \\
\hline Yes & 53.8 \\
\hline No & 27.2 \\
\hline Don't know & 15.8 \\
\hline Total & 100.0 \\
\hline
\end{tabular}

The questionnaire also included a question concerning potential barriers to the respondents' participation in their LAG. The most frequently mentioned barrier was lack of financial resources, which had a mean ranking of almost 3 on a scale from 1 (no barrier) to 4 (major barrier), but with a standard deviation close to 1 which indicates a divided view on the issue.

It thus appears that the less you are able to participate yourself, the less satisfied you are with the participation in the LAGs.

\section{Throughput legitimacy}

All regions score well on the throughput aspects as fair influence on discussions, decisions based on exchange of arguments, access to information, and accountability. These scores are consistently above $60 \%$ and only under $10 \%$ of the respondents score them as low or very low. Table 6 provides a representative example:

Tab 6. "To what extent do you consider your LAG decision-making process to provide fair opportunities for all participants to influence the content of your discussions?"

\begin{tabular}{|l|c|}
\hline$(\mathrm{N}=158)$ & Percentage \\
\hline No reply & 6.3 \\
\hline Low / very low extent & 6.9 \\
\hline Medium extent & 19.0 \\
\hline High / very high extent & 68.1 \\
\hline Total & 100.0 \\
\hline
\end{tabular}

The responses to all the questions concerning exchange of arguments seem to vary somewhat with where people live. People who claimed that they lived in central areas tend to rate LAGs more negatively than those in rural areas. This finding is applicable to all the following questions as well.

The responses to the questions regarding discussion, possibility to influence, access to information, and accountability had high internal consistency $(r>0.695)$. This means that they measured related attitudes or views. Consequently, there is a majority that seems very content with the internal workings of the LAGs in (almost) all its aspects, while there is a small minority that is discontent with (almost) every discussion. All aspects of throughput legitimacy are perceived to be rather similar, as presented in table 7 . 
Tab 7. Dimensions of throughput legitimacy presented in means, and measured on the scale 1 (very low) to 5 (very high).

\begin{tabular}{|l|c|c|c|}
\hline$(\mathrm{N}=158)$ & Mean ranking & $\begin{array}{c}\text { Standard } \\
\text { deviation }\end{array}$ & No reply \\
\hline $\begin{array}{l}\text { Fair opportunities for all participants to } \\
\text { influence the content of your discussions }\end{array}$ & 3.90 & 0.88 & $6.3 \%$ \\
\hline $\begin{array}{l}\text { Effective exchange of arguments amongst } \\
\text { participants }\end{array}$ & 3.73 & 0.85 & $6.3 \%$ \\
\hline $\begin{array}{l}\text { Access and obtain information about the } \\
\text { topics for discussion in your LAG }\end{array}$ & 3.83 & 0.88 & $5.7 \%$ \\
\hline $\begin{array}{l}\text { Accountable to the citizens for their } \\
\text { decisions and their performance }\end{array}$ & 3.95 & 0.98 & $6.3 \%$ \\
\hline
\end{tabular}

However, it should be noted that for accountability the standard deviation is higher than for the other aspects. This signals differences in perception on these issues cannot be said to depend solely on a general positive or negative image of the LAGs.

We can observe that the scores on throughput legitimacy are significantly higher than those on input legitimacy. This suggests that the main barriers to LAG work is more related to external than internal factors.

\section{Output legitimacy}

The measures for output legitimacy are based on the general question regarding whether the LAGs produce goods for the members. The answers are presented in table 8 . More than $60 \%$ of the respondents perceive the LAGs to be beneficial to their organization to a high or very high extent while less than $6 \%$ hold utility to be low or very low.

Tab 8. To what extent are LAG decisions beneficial for your organization?

\begin{tabular}{|l|c|}
\hline$(\mathrm{N}=158)$ & Percentage \\
\hline No reply & 10.1 \\
\hline Low / very low extent & 5.7 \\
\hline Medium extent & 32.9 \\
\hline High / very high extent & 51.2 \\
\hline Total & 100.0 \\
\hline
\end{tabular}

The correlations between output and throughput legitimacy are around 0.5 . Consequently, there is rather strong indication that these dimensions are connected. This could mean that a LAG member who sees the LAGs as fair is very likely to also see them as producing goods, and vice versa, and that a LAG member who does not perceive the LAGs as producing goods, is likely to see the LAG as unfair. Or it could mean that satisfaction with the process also produces satisfaction with the outcomes.

LAGs' usefulness as contributor to adaptation may be seen as a variable for output legitimacy, but this depends on the importance that climate change adaptation is assigned by the individual participants. We will here not assume that this is automatically seen as beneficial for them, which is indeed the definition of output legitimacy provided here. However, it is still interesting to look at the respondents' view on the impact of LAG work on adaption to climate change locally, and this reveals that the workshop participants showed less belief in the LAGs' usefulness as contributors to adaptation than its usefulness in providing benefits for their organisation. However, as shown 
in table 9 , only $21 \%$ of the respondents had low or very low expectations while one third of the respondents had high or very high expectations.

Tab 9. To what extent do you expect the LAG work to result in improved adaptation to climate change locally.

\begin{tabular}{|l|c|}
\hline$(\mathrm{N}=158)$ & Percentage \\
\hline No reply & 6.3 \\
\hline Low / very low extent & 20.9 \\
\hline Medium extent & 39.9 \\
\hline High / very high extent & 32.9 \\
\hline Total & 100.0 \\
\hline
\end{tabular}

These numbers indicate that a majority of the LAG members expect to play some role or can be counted upon to take part in adaptation initiatives. The expectations to the LAGs as playing a role in adaptation were lower among people living in towns and cities. There is a correlation between the findings in table 8 and table 9 , as would be expected. This correlation is just below 0.5 , which is just as strong as the relationships between the different parameters used to measure input and throughput legitimacy. The correlations between some dimensions of input and output legitimacy are lower. For the question on actual participation, the correlation is 0,250 , while for inclusion of stakeholders it is 0.289 , and for the perceived lack of financial resources as a barrier to efficient work the correlation is 0.348 .

\section{Legitimacy in the Czech LAGs - discussion}

As noted above, the two variables on experienced participation and the inclusion of stakeholders are strongly correlated $(r=0,645)$. These two variables seem to correlate to a medium degree with the responses to the questions relating to throughput legitimacy. The correlations for inclusion of stakeholders to aspects of throughput legitimacy are stronger than the correlations between experienced participation and throughput legitimacy. The responses to the question whether or not the right people participate in the LAGs do not correlate to any other issues whether in terms of input, throughput or output legitimacy. The responses to the perceived barriers have only very low correlations to throughput and output legitimacy.

Lederer (2011) describes a connection in the perception of outcome and throughput dimensions of legitimacy. We also find medium strong correlations between the aspects of throughput legitimacy and the aspects of output legitimacy $(r>0.5)$. This can serve as an indicator to how the process and outcome are connected.

The percentage of people who see their LAG as having a high or very high extent of inclusion and degree of participation is around $35 \%$, with $30 \%$ to $35 \%$ reporting a medium extent, and a little over $50 \%$ confirming that the right people are present in their LAG. This unclear status of input legitimacy seems to fit well with the conclusions from other contributions showing large variations in the cooperation with local people (European Court of Auditors 2010; Pechrová and Boukalová 2015); adequate, but descending representation of farmers (Delin 2012); and lack of partnership, network and cooperation (Hudečková \& Lošták 2008; Lošták \& Hudečková 2010).

The respondents' views on throughput legitimacy are more positive and less negative compared to input legitimacy. This is a positive finding given that the LAGs are supposed to engage qualitatively with citizens (Thuesen 2011), but surprising given the European Court of Auditors' (2010) and others' (Hudečková \& Lošták 2008; Lošták \& Hudečková 2010) observations on lack of transparency and involvement.

However, it might well be that the experienced qualities are different from the inside than from the outside since Katona-Kovács et al. (2011) find that traditional values play a large part in the Hungarian LAG's decision-making. A lack of transparency will typically lead to a situation 
where outsiders are not able to control the throughput qualities inside the LAGs. However, the correlations between the perceived utility of the LAGs for one's organization and the throughput qualities of the LAGs might indicate that the benefits one experiences to some degree might influence a LAG member's perception of the throughput qualities. It could be the case that the findings on throughput, as well as for output legitimacy, might be affected by the selection of respondents since it is reasonable to assume that the participants on the workshops are engaged in and for LAGs.

When it comes to utility for the organizations, the respondents marked this as less positive than the throughput qualities. Very few perceived the utility to be low or very low. The scoring of output legitimacy can be related to the points made by Maurel (2008) that the municipalities submit most of the funded projects, and that the organizations do not experience utility. This hypothesis is somewhat supported by the finding that representatives from public organisations perceived higher utility than those from private sector as illustrated in table 10.

Tab 10. To what extent are LAG decisions beneficial for your organization? Answers grouped by public, private, voluntary sector.

\begin{tabular}{|l|c|c|c|}
\hline Sector $(\mathrm{N}=135)$ & Very high / high extent & Medium extent & Low / very low extent \\
\hline Public & $55.3 \%$ & $38.2 \%$ & $2.9 \%$ \\
\hline Private & $42.8 \%$ & $50.0 \%$ & $0 \%$ \\
\hline NGO & $53.6 \%$ & $26.8 \%$ & $7.2 \%$ \\
\hline
\end{tabular}

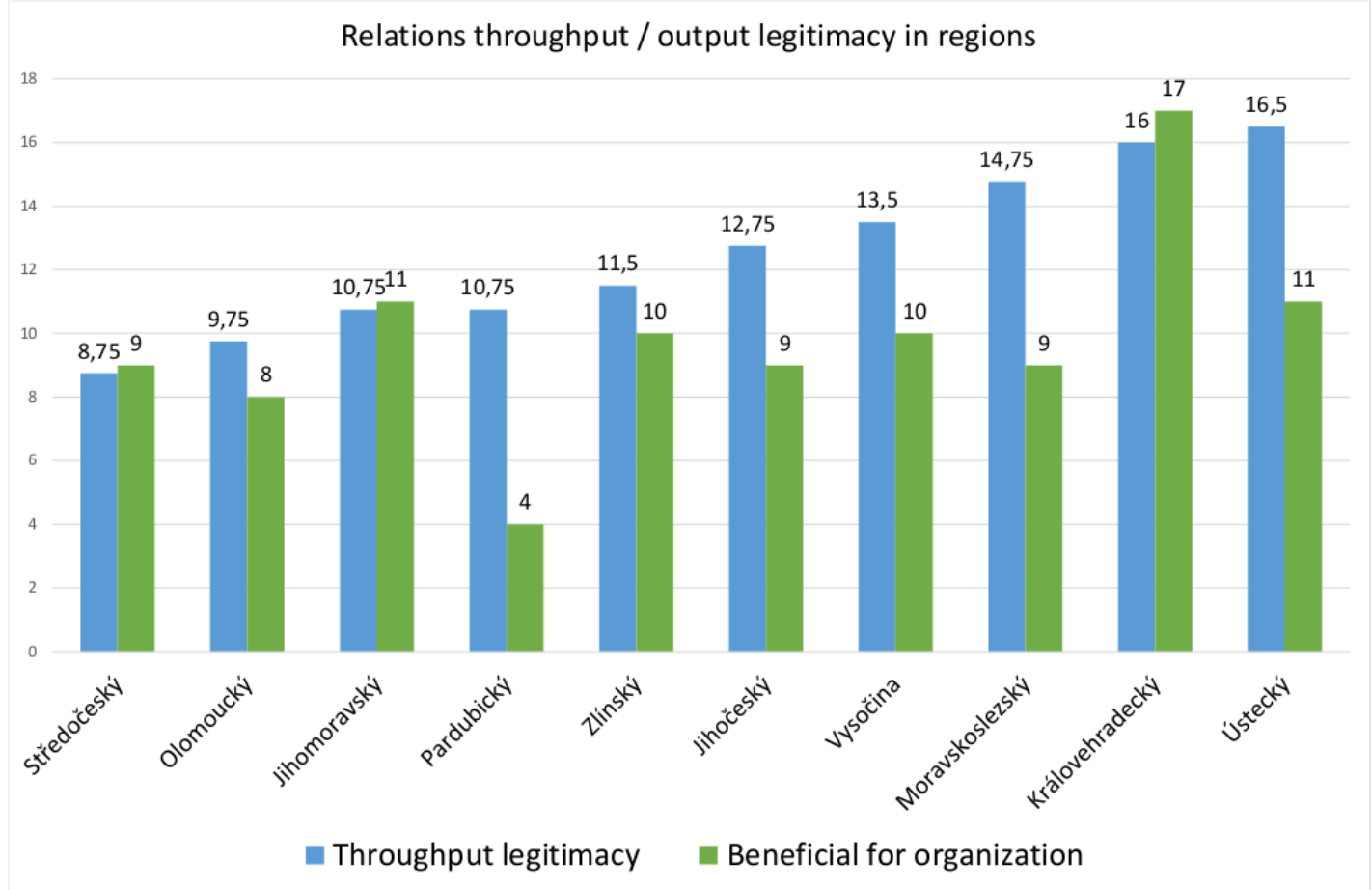

Fig 2. Summarized scores on output legitimacy dimensions in relation to summarized scores on throughput legitimacy distributed by regions. ${ }^{5}$

\footnotetext{
5 These sums have been created by assigning the following numerical scores to the alternatives: Very high $=2$; High $=1$; Medium = 0; Low = 1 ; Very low = -2 , and thereafter calculated the mean score for throughput legitimacy.
} 
These frequencies are not conclusive, but do seem to indicate that respondents from the private sector see less utility from the LAGs than public sector respondents. One reason one could expect high degrees of perceived utility across sector can be found in the European Court of Auditors' (2010) general observation that most grants go to LAG member organizations, exactly the ones that make up the population in this survey.

The medium to high extent of perceived output legitimacy could further be understood with Hudečková and Lošták's (2008) findings that there is an ambivalence in the use of funds. The farmers' needs are taken into account, but the spending is rather directed towards infrastructure than collective actions.

Pechrová and Boukalová (2015) state that there are great local differences between the LAGs. However, there does not seem to be anything in the responses that show that there are any consistent covariation between the sum total in perception of throughput legitimacy in any region and the output legitimacy in the same region.

Figure 2 illustrates that there are no systematic regional correlations between the perceived throughout and output legitimacy of the LAGs.

LAG members are part of LAGs because of its role in regional development. The LAGs appear reasonably well organised for this work, as indicated by their relatively good score on throughput legitimacy and on the question of benefits to participants. It is important that the use of LAGs as a climate adaptation instrument does not jeopardise these positive traits, affecting the overall internal legitimacy of the LAGs. If climate change adaptation effects are to be an important output of LAG work, the LAGs need to uphold their overall internal legitimacy.

Table 11 show the respondents' ranking of proposed actions for adaptation to climate change:

Tab 11. Percentage responded "yes" to the question: "In order to adapt to climate change responsibly the following actions are what are primarily needed".

\begin{tabular}{|l|l|}
\hline Actions: & Yes \% \\
\hline Increased awareness among stakeholders, the public and politicians & 61.4 \\
\hline More research about climate change and ways how to mitigate it & 46.2 \\
\hline A stronger moral stance among stakeholders, the public and politicians & 40.5 \\
\hline Improvement of regulation (laws, decrees, norms) & 39.9 \\
\hline $\begin{array}{l}\text { Integration of already existing research about climate change and ways how to } \\
\text { mitigate it }\end{array}$ & 39.2 \\
\hline Improved dialogue between stakeholders & 36.7 \\
\hline Involvement of the public & 32.9 \\
\hline Economic incentives & 17.7 \\
\hline
\end{tabular}

In alignment with the demands and ideals of local learning across sectors in the LEADER programme, LAGs can be an instrument for increased awareness, if LAGs continue to be seen as a legitimate and attractive forum. The material shows that there is a correlation between several of the parameters on perceived input legitimacy and output legitimacy. A hypothesis could be that the input factors need to be considered adjusted if the LAGs are to play a positive and forceful role in adaptation and resilience building. This would be an important topic for further qualitative research. 


\section{Conclusions}

It is an aim of this article and this project to provide feedback to LAGs on themselves as organizations embedded in different local contexts seen through the lenses of legitimacy, and in this way build upon the co-operative model of neo-endogenous development.

The Czech Local Action Groups seem to be in a transition period from an infancy and start-up towards becoming mature and established. The survey conducted in connection with the project workshops has documented that lack of financial resources is seen as a barrier for participation in the LAGs, which impacts on the LAGs' functioning. However, this barrier is not related to throughput and output legitimacy, which overall are positively rated. The study suggests that LAGs ought to consider their composition since this was a variable where one out of four respondents were not happy.

If we take as a point of departure Ensor and Berger's (2009) view that resilient strategies must be developed in a participatory way and Moser and Ekstrom's (2010) finding that a lack of legitimacy might obstruct the implementation of adaptation measures, the moderate estimation of input legitimacy in the LAGs should be a cause for some worries. When there is a moderate support for the LAGs from the LAG members themselves as to the composition of the institution, then there seems to be a need to open up a debate on the composition of the LAGs and their engagements with stakeholders in order to make them efficient agents for adaptation to climate change. One concrete manifestation of this need, was the outcome of the current project's stakeholder workshop in Hradec nad Moravicí on October $21^{\text {st }}, 2015$. During this workshop, several of the mayors present argued that one specific institution that could increase local resilience was the voluntary fire brigades. The workshop participants held that the local knowledge and the specific disaster risk reduction capacities of local firefighters is crucial to uphold local resilience. This viewpoint resonates well with Dostál's (2012) point that local firefighters hold a central place in the Integrated Rescue System in the Czech Republic.

When it comes to such wider co-operation, Dax et al. conclude:

"[...] a more active engagement with other sectors and actors will be required in order to tap the local potential of rural (and urban) regions. In this respect, future Leader and local development actions need to reinvigorate longestablished core principles, most notably the notion of social innovation and to concentrate on local and regional assets and deliver at that level, if its capacity to make a significant area-specific impact is to be realized again. $(2016,66)$

This conclusion of a novel way of re-thinking the local community seems to fit well with the findings and experiences of this study, and is further supported by other studies (Hudečková \& Lošták 2008; European Court of Auditors 2010; Lošták \& Hudečková 2010). It is further in line with the description by Thuessen (2016) on the expansion of LAGs in Denmark to greater inclusion and an increase in input legitimacy. Policymakers need to consider appropriate participation if LAGs are to work as an important instrument for supporting climate change adaptation in local communities and building awareness of the issues.

The throughput aspect of legitimacy can be related to the issues raised by Sørensen (2001) and Winsvold et al. (2009) concerning the rules and procedures that are important for democracies. The workings inside of the LAGs are to a large degree positively evaluated. In general, this suggests that there exist safeguards in the LAGs against granting money to poorly designed projects, and that the respondents themselves perceive the LAG working methods as orderly and responsible. However, the discrepancy between respondents when it comes to perceived accountability should be taken into account. Consequently, it could be argued that the LAGs themselves should have a greater role in deciding the political priorities of the funding schemes and that the current auditing rules and the regulatory and bureaucratic centralization, which other studies report as burdensome (Dax et al. 2016) should be rethought towards decentralization. Thuesen and Nielsen (2014) likewise find unique added values in LAG self-governance that point in the direction of expanding the LAGs' decision-making capacities. Some of the literature on Czech LAGs present the throughput dimensions of legitimacy in a negative light while the LAGs 
themselves see the throughput dimension as unproblematic. This gap in perspectives should be addressed by the LAGs in communications with the local communities and their users.

One third of the respondents perceive the LAGs to be very or highly efficient in adaptation to climate change. One possible interpretation is that they see adaptation as different from regional development since over 50\% see the LAGs as beneficial for their organisation in general terms (Scott 2013). If this interpretation is valid, then it is likely that further training or awareness-rising amongst the LAG members on how to combine adaptation and development would be a suitable remedy. It is more likely that LAGs will be able to combine local values with adaptation efforts than central governmental decisions, and thereby create lasting adaptation - and hence resilience (van Aalst et al. 2008). Such training could well be done through extended co-operation with existing local resources.

Limitations of this study should addressed by conducting further research. As we here have focused on internal legitimacy, it would be interesting to conduct a study involving external stakeholders to the same LAGs as were included here. Moreover, more qualitative data would be useful to supplement the survey. We believe, however, that we have provided a useful analytical framework for further studies and that the data provided in this article are an interesting contribution to policy in this area and give better understanding of legitimacy dimensions affecting the potential to use regional developments networks to adapt to climate change.

\section{Acknowledgements}

We wish to thank the National Network of Local Action Groups in the Czech Republic for extensive support in gaining access to members and places, and especially the help from the MAS Opavsko. This has been invaluable and is much appreciated. Furthermore, we wish to acknowledge the input from and discussions with Jakub Dlabka, Yvonna Gaillyová, and Kamila Danihelková. The workshops would not have been possible without the important contributions from Jan Hollan, Jaroslav Rožnovský and Jiří Krist, and depended on the kind hospitality of ten host institutions as well as the organizational skills of Veronika Foltýnová.

The research is supported by Norway and EEA grant through the project "Resilience a adaptace na klimatickou změnu", EHP - CZ02-OV-1-017-2014

References

[1] Bäckstrand, K. (2008). Accountability of Networked Climate Governance: The Rise of Transnational Climate Partnerships. Global Environmental Politics, 8(3), 74-102. DOI: $10.1162 /$ glep.2008.8.3.74.

[2] Beck, U. (2006). Reflexive governance: politics in the global risk society. In Voss, J.-P., Bauknecht, D. \& Kemp, R. (Eds.), Reflexive governance for sustainable development (pp. 31-56). Cheltenham, UK; Northampton, MA: Edward Elgar.

[3] Bulkeley, H., \& Newell, P. (2010). Governing climate change. London; New York: Routledge.

[4] Dax, T., Strahl, W., Kirwan, J., \& Maye, D. (2016). The Leader programme 2007-2013: Enabling or disabling social innovation and neo-endogenous development? Insights from Austria and Ireland. European Urban and Regional Studies, 23(1), 56-68. DOI: $10.1177 / 0969776413490425$.

[5] Deephouse, D. L. \& Suchman, M. (2008). Legitimacy in organizational institutionalism (pp. 49-77). The Sage handbook of organizational institutionalism, 49.

[6] Delin, M. (2012). The role of farmers in Local Action Groups: The case of the national network of the Local Action Groups in the Czech Republic. Agricultural Economics (Zemědělská ekonomika), 58(9), 433-442.

[7] Dingwerth, K. (2007). The New Transnationalism: Private Transnational Governance and its Democratic Legitimacy. Basingstoke, New York: Palgrave Macmillan. 
[8] Dostál, J. (2012). Cooperation between non-governmental organizations and the State in the matter of flood risk management in the Czech Republic. In Proverbs, D. G. ed., Flood recovery, innovation and response III (pp. 15-26). Southampton: WIT Press. DOI: 10.2495/FRIAR120021.

[9] Dwyer, J. \& Findeis, J. (2008). Human and Social Capital in Rural Development - EU and US Perspectives Human- und Sozialkapital in der Entwicklung des ländlichen Raums Perspektiven aus der EU und den USA Le capital social et humain dans le développement rural: Perspectives aux États-Unis et dans I'Union européenne. EuroChoices, 7(1), 38-45. DOI: 10.1111/j.1746-692X.2008.00084.X.

[10] ECONADPT. (2015). The Costs and Benefits of Adaptation: Results from the ECONADAPT Project. The ECONADAPT consortium. Retrieved from http://econadapt.eu/docs/Econadaptpolicy-report-on-costs-and-benefits-of-adaptaiton-july-draft-2015.pdf.

[11] Ensor, J. \& Berger, R. (2009). Community Based Adaptation and Culture in Theory and Practice. In Adger, W. N., Lorenzoni, I. \& O'Brien, K. L. (Eds.), Adapting to climate change: thresholds, values, governance (pp. 227-239). Cambridge ; New York: Cambridge University Press.

[12] European Commission. (2006). The Leader approach: a basic guide. Luxembourg: EUR-OP. Retrieved from http://ec.europa.eu/agriculture/publi/fact/leader/2006_en.pdf.

[13] European Commission. (2010). Eurobarometer. 1. Life in the European Union (Standard Eurobarometer No. 70) (p. 209). European Commission. Retrieved from http://ec.europa.eu/public_opinion/archives/eb/eb70/eb70_part1_en.pdf.

[14] European Commission. (2013). An EU Strategy on adaptation to climate change. (Communication from the Commission to the European Parliament, the Council, the European Economic and Social Committee and the Committee of the Regions No. COM (2013) 216 final). Brussels: European Commission. Retrieved from http://eurlex.europa.eu/legal-content/EN/TXT/PDF/?uri=CELEX:52013DC0216\&from=EN.

[15] European Court of Auditors. (2010). Implementation of the Leader approach for rural development: (pursuant to Article 287(4), second subparagraph, TFEU). Luxembourg: Publications Office of the European Union.

[16] Forsberg, E.-M. (2012a). Applying instruments for regional innovation - generating projects or legitimacy? International Journal of Innovation and Regional Development, 4(5), 430-445. DOI: 10.1504/IJIRD.2012.048995.

[17] Forsberg, E.-M. (2012b). Standardisation in the Field of Nanotechnology: Some Issues of Legitimacy. Science and Engineering Ethics, 18(4), 719-739. DOI: 10.1007/s11948-0119268-0.

[18] Glaas, E., Jonsson, A., Hjerpe, M. \& Andersson-Sköld, Y. (2010). Managing climate change vulnerabilities: formal institutions and knowledge use as determinants of adaptive capacity at the local level in Sweden. Local Environment, 15(6), 525-539. DOI: $10.1080 / 13549839.2010 .487525$.

[19] Hudečková, H. \& Lošták, M. (2008). LEADER in the Czech Republic and farming sector. Agricultural Economics (Zemědělská ekonomika), 54(12), 555-565.

[20] IPCC. (2014). Climate change 2014: impacts, adaptation, and vulnerability: Working Group II contribution to the fifth assessment report of the Intergovernmental Panel on Climate Change. New York, NY: Cambridge University Press.

[21] Katona-Kovács, J., High, C. \& Nemes, G. (2011). Importance of Animation Actions in the Operation of Hungarian Local Action Groups. European Countryside, 3(4), 227-240. DOI: 10.2478/v10091-012-0006-7. 
[22] Kumar, R. \& Das, T. K. (2007). Interpartner Legitimacy in the Alliance Development Process*. Journal of Management Studies, 44(8), 1425-1453. DOI: 10.1111/j.14676486.2007.00709.x.

[23] Lederer, M. (2011). From CDM to REDD+ - What do we know for setting up effective and legitimate carbon governance? Ecological Economics, 70(11), 1900-1907. DOI: 10.1016/j.ecolecon.2011.02.003.

[24] Lošt’ák, M. \& Hudečková, H. (2010). Preliminary impacts of the LEADER+ approach in the Czech Republic. Agricultural Economics (Zemědělská ekonomika), 56, 249-265.

[25] Low, B. \& Johnston, W. J. (2010). Organizational network legitimacy and its impact on knowledge networks: the case of China's TD-SCDMA mobility technology. Journal of Business \& Industrial Marketing, 25(6), 468-477. DOI: 10.1108/08858621011066053.

[26] Majule, A. E., Stathers, T., Lamboll, R., Liwenga, E. T., Ngongondo, C., Kalanda-Joshua, M., Swai, E. \& Chipungu, F. (2013). Enhancing capacities of individuals, institutions and organizations to adapt to climate change in agricultural sector using innovation system approaches in Tanzania and Malawi. World Journal of Agricultural Sciences, 1(6), 220-231.

[27] Maurel, M.-C. (2008). Local Development Stakeholders and the European Model: Learning the LEADER Approach in the New Member States. Czech Sociological Review, 44(3), 511530.

[28] Moser, S. C. \& Ekstrom, J. A. (2010). A framework to diagnose barriers to climate change adaptation. Proceedings of the National Academy of Sciences, 107(51), 22026-22031. DOI: $10.1073 /$ pnas. 1007887107.

[29] National Network of Local Action Groups in the Czech Republic. (2011, May). NATIONAL STRATEGIC PLAN. LEADER 2014+. Retrieved from http://nsmascr.cz/content/uploads/2012/07/NATIONAL-STRATEGIC-PLAN-LEADER2014+-SUMMARY.pdf.

[30] OECD. (2014). Society at a Glance 2014. OECD Publishing. Retrieved from http://www.oecd-ilibrary.org/social-issues-migration-health/society-at-a-glance2014_soc_glance-2014-en.

[31] OECD. (2015). Climate Change Risks and Adaptation. OECD Publishing. Retrieved from http://www.oecd-ilibrary.org/environment/climate-change-risks-andadaptation_9789264234611-en.

[32] Parsons, T. (1960). Structure and process in modern societies. Glencoe, III.: Free Press.

[33] Pechrová, M. \& Boukalová, K. (2015). Differences Among Czech Local Action Groups In Using Selected Principles Of Leader*. Scientia Agriculturae Bohemica, 46(1), 41-48. DOI: $10.1515 / \mathrm{sab}-2015-0015$.

[34] Persson, S. G., Lundberg, H. \& Andresen, E. (2011). Interpartner legitimacy in regional strategic networks. Industrial Marketing Management, 40(6), 1024-1031. DOI: 10.1016/j.indmarman.2011.06.027.

[35] Ray, C. (1999). Endogenous Development in the Era of Reflexive Modernity. Journal of Rural Studies, 15(3), 257-267. DOI: 10.1016/S0743-0167(98)00072-2.

[36] Ray, C. (2000). Editorial. The EU leader Programme: Rural Development Laboratory. Sociologia Ruralis, 4O(2), 163-171. DOI: 10.1111/1467-9523.00138.

[37] Scott, M. (2013). Resilience: a Conceptual Lens for Rural Studies? Geography Compass, 7(9), 597-610. DOI: 10.1111/gec3.12066.

[38] Sørensen, E. (2002). Democratic Theory and Network Governance. Administrative Theory \& Praxis, 24(4), 693-720. DOI: 10.1080/10841806.2002.11029383.

[39] Suchman, M. C. (1995). Managing Legitimacy: Strategic and Institutional Approaches. Academy of Management Review, 20(3), 571-610. DOI: 10.5465/AMR.1995.9508080331. 
[40] Thuesen, A. A. (2010). Partnership Organising of Rural and Coastal Development in Denmark (Ph.d.). Syddansk Universitet. Det Samfundsvidenskabelige Fakulter. Retrieved from http://static.sdu.dk/mediafiles/A/F/A/\%7BAFA43E21-7DCF-4BFC-A1C68DA4E1FDD6B8\%7DSamlet\%20LAG\%20afhandling.pdf.

[41] Thuesen, A. A. (2011). Partnerships as Associations: Input and Output Legitimacy of LEADER Partnerships in Denmark, Finland and Sweden. European Planning Studies, 19(4), 575-594. DOI: 10.1080/09654313.2011.548469.

[42] Thuesen, A. A. (2016). The Democratic Capabilities of and Rhetoric on LEADER LAGs in the EU - The Danish Case. In Granberg, L., Andersson, K. \& Kovách, I., eds., Evaluating the European Approach to Rural Development: Grass-roots Experiences of the LEADER Programme (pp. 79-93). Routledge.

[43] Thuessen, A. A. \& Nielsen, N. C. (2014). A Territorial Perspective On EU's Leader Approach In Denmark: The Added Value Of Community-Led Local Development Of Rural And Coastal Areas In A Multi-Level Governance Settings. European Countryside, 6(4). DOI: 10.2478/euco-2014-0017.

[44] Urwin, K. \& Jordan, A. (2008). Does public policy support or undermine climate change adaptation? Exploring policy interplay across different scales of governance. Global Environmental Change, 18(1), 180-191. DOI: 10.1016/j.gloenvcha.2007.08.002.

[45] Van Aalst, M. K., Cannon, T. \& Burton, I. (2008). Community level adaptation to climate change: The potential role of participatory community risk assessment. Global Environmental Change, 18(1), 165-179. DOI: 10.1016/j.gloenvcha.2007.06.002.

[46] Varga, E. (2009). Non-profit organizations in Hungarian rural development - a leader+ example in the southern Transdanubian region. European Countryside, 1(2), 93-103. DOI: 10.2478/v10091/009-0008-2.

[47] Ward, P. N., Atterton, D. J., Kim, T., Lowe, P. P., Phillipson, J. \& Thompson, D. N. (2005). Universities, the Knowledge Economy and "Neo-Endogenous Rural Development". Retrieved from http://eprint.ncl.ac.uk/pub_details2.aspx?pub_id=148470.

[48] Weber, M. (1947). The theory of social and economic organization (1. pbk. ed., reprint). New York, NY: Free Press.

[49] Weichselgartner, J. \& Pigeon, P. (2015). The Role of Knowledge in Disaster Risk Reduction. International Journal of Disaster Risk Science, 6(2), 107-116. DOI: 10.1007/s13753-0150052-7.

[50] Winsvold, M., Stokke, K. B., Klausen, J. E. \& Saglie, I. L. (2009). Organizational learning and governance in adaptation in urban development (pp. 476-490). In Adger, N., Lorenzoni, I. \& O'Brien, K., eds., Adapting to climate change. Thresholds, values, governance.

[51] Wynne, B. (1996). May the Sheep Safely Graze? A Reflexive View of the Expert-Lay Knowledge Divide. In Lash, S., Szerszynski, B. \& Wynne, B. (Eds.), Risk, environment and modernity: towards a new ecology (pp. 44-84). London; Thousand Oaks, Calif: Sage Publications. 